\title{
China's Baby Steps in Africa: A Historical Reckoning of Chinese Relations with Mozambique and Sudan until 2011.
}

\author{
David Robinson \\ Edith Cowan University \\ d.robinson@ecu.edu.au \\ Benjamin Hale \\ Edith Cowan University \\ bhale@our.ecu.edu.au
}

\begin{abstract}
China's presence in Africa has grown rapidly over the past two decades, as Africa's oil and minerals have become increasingly important for China's resource-hungry economy. China's network of relations with developing states began its expansion during the 1990s, and by the early Twenty First Century had become an increasing cause for concern amongst Western commentators. Critics of Chinese influence in Africa argue that China's economic relations are self-serving, and that their actions might detrimentally affect progress for democratisation, human rights, and sustainable development in Africa. Others argue that, in fact, Chinese policies aim to create long-term stability and development in African nations, on a mutually beneficial basis. This article will assess Chinese policies as implemented in the period up to 2011, in the two African nations of Sudan and Mozambique. Criticisms of Chinese relations with Africa will be considered, which commonly include that those relationships will hurt African economies, encourage corruption and authoritarianism, and threaten the security of African civilians. This article concludes that there is some truth to each of these criticisms, but that the reality is more complex, varies substantially from case to case, and does not preclude positive outcomes from these growing relations.
\end{abstract}




\section{Introduction}

The phenomenal economic rise of China and its growing presence in Africa has been the centre of much recent debate among international relations researchers (Raine, 2009; Scott, 2008; Friedman, 2010; Hofstedt, 2009). Ian Bremmer (2010) notes that, in their attempts to attain Great Power status, "[a]uthoritarian governments everywhere have learned to compete internationally by embracing market-driven capitalism" (p. 4). Having now undergone two decades of unprecedented capitalist expansion, Africa's oil and natural resources have motivated China to deepen relations with the continent in its quest to import increasing quantities of raw materials and energy products (Jakobson, 2009); indeed, Africa soon became China's second largest supplier of oil after the Middle East (Alden \& Alves, 2009). By the 1990s China's contact with Africa began to increase rapidly, with many observers noting that its attitude toward African states was often in contrast with the West's saviour narrative. At China's 2006 Forum on China-Africa Cooperation, for example, Kenneth King (2006) noted that:

the view of Africa in Beijing was one of life rather than death and disease; richness of colour and of culture rather than poverty; dynamism, energy and opportunity for business ... [were] highlighted, and not their poverty, disease and poor governance. (p. 6)

While these commentators have argued that the new Sino-African partnerships are "based on long-term stability, equality and mutual benefit" (Yi-Chong, 2008, p. 26), others have raised concerns about China's impact on issues of democratisation, human rights and sustainable development (Liang, 2008). Taylor (2008) highlights that, "[i]n a nutshell...China will do business with anyone, regardless of their human rights and/or democratic record" (p. 65). Three key criticisms are common in the literature regarding China and Africa, namely: 1) that China is primarily motivated by extractive economic interests in its relations with Africa and that this will only hurt African economies (Large, 2008); 2) that Chinese political and economic relations with African governments may encourage authoritarianism or corruption, or at least undermine Western efforts to correct these issues (Alden \& Alves, 2009); and 3) that Chinese military support is an important part of relations with African states, and may pose a human security threat to African civilians (Reeves, 2006). This article will set out the details of the economic, political and strategic relations between 
China and the African states of Mozambique and Sudan, and the impacts relations have had on these nations. Each case study will be examined in turn, before making a final assessment of the accuracy of these criticisms regarding the pre-2011 period.

It has been argued by some analysts that China's relations with the government of Sudan constitute an important case study of China sustaining an undemocratic regime and undermining Western sanctions (Pant, 2008). China's ambiguous position in relation to the Darfur Genocide-providing peacekeepers and supporting a peace process while still backing the Government of Sudan-was far from satisfactory for many observers (Large, 2008; 2016). Mozambique is another state that has embraced relations with China although, in contrast to Sudan, the former Portuguese colony has been heralded as a poster child for Western-backed democratisation and economic reform (Reisinger, 2009). During the period under study (1994-2011) Mozambique had one of the fastest growth rates in trade and investment with China of any single nation, with the evolution of the Sino-Mozambican relationship described by Horta (2007) as "just short of meteoric" (p. 1). The intensity of this relationship was later affirmed in 2016, when Mozambique became the first African nation to upgrade relations with China through a 'Partnership and Global Strategic Cooperation Agreement', strengthening bilateral relations in all fields (Club of Mozambique, 2016; Macauhub, 2016; Stremlau, 2015). Mozambique's relationship with China in this period was also interesting for three reasons: it was not centred on oil or gas; Mozambique is one of the least-developed nations on earth; and Mozambique also had strong international relations with the West. Indeed, it was cited as a political and economic 'success story' of Western influence in Africa through aid and cooperation (Reisinger, 2009).

This article examines China's developing relationships with Sudan and Mozambique in the pre-2011 era. The aim is to compare and contrast the political, economic and strategic forms these relationships have assumed, evaluate how they have affected the nations under investigation, and assess how they reflect on broader debates about China's aims and impacts in Africa. The year 2011 has been chosen as an appropriate date for periodisation for this study due to a number of factors. At the beginning of 2011 the southern half of Sudan formally proclaimed its independence as South Sudan - dramatically altering the dynamics of Chinese relations with those states. For Mozambique, 2011 marked a turning point due, on the one hand, to the eruption of new political instability related to popular protests and the remilitarisation of the RENAMO opposition movement and, on the 
other hand, due to the discovery of massive offshore gas reserves (Freedom House, 2012; Macauhub, 2017). Additionally, China's broader continental and global relations were affected in 2011 by the move to prioritise South Africa as an African partner through its acceptance into the political and economic BRICS alliance (Smith, 2011) and the Obama administration's announcement of a geostrategic 'pivot to Asia' later that year (Clinton, 2011). Some observers described this move as the de-prioritisation of containing Chinese influence in Africa, as evidenced by the "downgrading of Africa [as] contained in official expressions of U.S. grand strategy since 2011" (Gaudilliere, 2014, p. 5).

This article will argue that analysis of the details of China's relations with Mozambique and Sudan in the period under study supports the claim that, economically, China has been primarily driven by the aim of extracting natural resources, but that this has not necessarily been negative for African economies. Further, it indicates that Chinese activities have lessened Western leverage to induce reforms, but only in cases where Western leverage was already minimal. And, finally, that while military support was not a primary driver of China's relations with African states, in the cases of oppressive governments, such as in Sudan, Chinese assistance may empower regimes in the violent repression of their citizens.

\section{China and Africa from an international relations perspective}

Describing China's changing relationship with Africa, Campbell (2008) quotes both Antonio Gramsci that, "the old is dying yet the new is yet to be born", and Chinese leader $\mathrm{Hu}$ Jintao that "China and Africa share increasing common interests and have a growing mutual need" (p. 92). The expanding literature on Sino-African relations reflects this deepening engagement, with concerns ranging from "control over energy resources to exploitive economic practices and support of rogue or corrupt regimes, perpetuating instability and undermining international pressure for reform" (Hofstedt, 2009, p. 79). Western commentators such as Pant (2008), Halper (2010) and Scott (2008) are critical of Chinese involvement in African countries, labelling Chinese foreign policy as self-serving and neocolonialist. They argue that China promotes harmful environmental practices, fosters corruption, and undermines International Monetary Fund (IMF) efforts to enhance transparency and combat poverty. However, many Africans view China favourably when compared to the US and, given the failure of the IMF's Structural Adjustment Programs, view China's statesupported model of growth as an attractive alternative to neo-liberal policy prescriptions (Jacques, 2009). 
Recent research in South Africa and Nigeria confirms that many Africans view the United States and China as the best examples of developed economies in roughly equal numbers (Poushter, 2016). Since the early establishment of Sino-African relations in the late 1950s, China has developed from a marginal actor to an influential player on the continent. Official Chinese Communist Party (CCP) documents divide China's economic and trading relations with Africa into three distinct periods: 19491978, 1979-1994, and 1995 onwards, with the emphasis shifting from ideological and diplomatic engagement to more pragmatic economic and commercial interests (Campbell, 2008). Lauren Johnston (2016) concurs, labelling these periods as: 'Political Alliances' 1950-1979; 'Independent Development' 1979-1995; 'Interdependent Development' 1995-2013; and adding a fourth period of 'Comprehensive Development' 2013-present.

The first period of modern Chinese engagement with Africa coincided with the period of decolonisation following World War Two. It was forged heavily in the rhetoric of unity in the anti-colonial struggle and solidarity between developing nations, and institutionalised in the 1955 Bandung Conference, the Afro-Asian People's Solidarity Organisation and the NonAligned Movement (Mohan \& Power, 2008). Throughout the next few decades, China provided support to several African independence struggles and assisted newly independent African nations by providing doctors, technical experts, and infrastructure (Jakobson, 2009). By the 1980s China's activity in Africa had shrunk dramatically (Yi-Chong, 2008) but, after China experienced international isolation following the 1989 Tiananmen Square Massacre, Chinese diplomats increasingly sought contacts throughout the developing world (Jakobson, 2009). African leaders responded positively to Chinese overtures, and their growing diplomatic relations were strengthened with the rising importance of energy resources to China's foreign policy in the 1990s (Mohan \& Power, 2008).

China's drive to diversify its energy sources followed its transition to a net oil importer in 1993 (Human Rights Watch, 2003; Hong, 2011). Oil quickly came to constitute 80 percent of China's imports by value, making Africa China's second largest supplier of oil after the Middle East, and China the second largest destination for African oil after the United States (Alden \& Alves, 2009). Sino-African trade increased by around 30 percent each year from 2002 (reaching US\$114.8 billion in 2010 despite the financial crisis) (Sutter, 2012; BBC News Online, 2009), making China Asia's leading importer of African products and Africa's third largest trading partner after the United States and France (Broadman, 2007; Jakobson, 2009). 
Chinese investment in Africa grew by a factor of 300 between 1990 and 2007 to around US\$14 billion (Naidu, Corkin, \& Hermin, 2009). A notable area for this was in enhancing Chinese food security, with growing efforts to secure land to produce food for export to China (Raine, 2009; Xinhua, 2008). Chinese Foreign Direct Investment (FDI) inflows to Africa primarily concentrated on the extractive industries, but there was some diversification into other sectors (Broadman, 2007). Detailed analysis shows that over this period China had only "a modestly stronger attraction to natural resources" than Western investors (Chen, Dollar, \& Tang, 2015, p. 7). The importance of securing energy and food resources for China cannot be overstated, with sustained economic growth and resource security being central to the CCP regime's survival (Cornelius \& Story, 2007). The deepening China-Africa relationship became incontrovertible following the official proclamation of 2006 as 'China's Year of Africa', with 48 African leaders hosted in Beijing at the Forum on China-Africa Cooperation, and extensive touring of African capitals by members of the Chinese leadership (Jakobson, 2009; Pant, 2008).

Throughout this period China forged strong relationships in Africa through a diverse array of projects and policies concerning business and aid - described by some as a 'noodle bowl' approach (Johnston \& Yuan, 2014). China cancelled almost US\$3 billion of African debt (Bräutigam, 2010), pledged US\$10 billion in concessional loans to African countries (Horta, 2009), expanded scholarship programmes for tens of thousands of Africans to study in China, and built hundreds of schools and medical centres in Africa (Hofstedt, 2009). China also invested billions of dollars a year in funding roads, railways, dams and power projects across Africa that had been neglected as unprofitable by Western aid agencies and businesses (Naidu, Corkin, \& Hermin, 2009). Together with China's role as the "selfproclaimed champion of the developing world ... [giving] a voice to lessdeveloped countries in institutions largely dominated by Western interests" (Currier \& Dorraj, 2011, p. 4), these efforts helped China to successfully enlist African support at the United Nations to block eleven UN condemnations of Chinese human rights abuses, and increase Taiwan's international isolation (Alden, 2007; Hofstedt, 2009).

Commentators noted that the willingness of Chinese policymakers to "adapt their strategies to suit the particular histories and geographies of the African states with which they engage" (Carmody \& Taylor, 2010, p. 497) has been a critical factor in China's success in forging Sino-African relations, both in terms of cynically manipulating systems and providing real desired outcomes for elites and populations (Jakobson, 2009). 


\section{China and Mozambique}

China's first contact with Mozambique may have been during the sixteenth century, and Portuguese recruitment of Chinese workers into the colony from the mid-1800s meant that Mozambique hosted a Chinese community of around 20,000 at independence in 1975 (Chichava, 2008; Ilhéu, 2010). During Mozambique's War of Independence, commencing in the 1960s, China supplied training, equipment and money to various Mozambican liberation organisations, and was among the first countries to subsequently recognise the FRELIMO party government (Chichava, 2008). Sino-Mozambican relations cooled shortly thereafter, due to Mozambique assuming positions on international issues at odds with China, but improved in the early 1980s and have sustained low-level trade and aid relations into the 1990s (Jackson, 1995; Taylor, 2006).

Since the late 1990s the Sino-Mozambican relationship has flourished, beginning with the 1997 establishment of a US\$20 million incentive fund for Chinese companies to operate in Mozambique, and the 2001 creation of a Joint Economic and Trade Commission (Roque, 2009). Mozambique soon had one of the fastest growth rates in trade and investment with China experienced by any single nation, and notably that growth was not driven by oil and gas (Horta, 2007 \& 2011). In turn, Mozambican politicians welcomed Chinese interest, with President Armando Guebuza making clear that they were "very satisfied with the support offered by China" (Ilhéu, 2010, p. 57), and that China was "a partner and not a colonizer" (Chichava, 2008 , p. 2). Beyond the political class, a number of independent surveys undertaken during the period found that Mozambicans generally welcomed the Chinese and that "members of Mozambique's civil society [were] generally enthusiastic about China's [aid] and [investment] projects" (Ilhéu, 2010 , p. 55). China's strong focus on building infrastructure made it a particularly appealing partner for a nation devastated by war (Roque, 2009), with former Prime Minister Luisa Diogo concluding that, although Mozambique, "should not close [its] eyes and forget [its] traditional partners... we need cooperation with China" (cited in Hanlon, 2010b, p. 2).

\section{Economic Relations}

$\underline{\text { Aid }}$

In the pre-2011 period a major share of economic input from China was in the form of aid. This encompassed Chinese grants for public projects, cheap loans, and programmes of social, cultural, technical and humanitarian cooperation. Programmes included hundreds of scholarships for 
Mozambican students to pursue higher education in China (Horta, 2011); training for 500 Mozambican professionals in China; the building of rural schools (Ilhéu, 2010); and funding for long-distance learning (AIM News, 2011). Medical assistance included free medical supplies (Ilhéu, 2010) and teams of Chinese doctors to work in Mozambican hospitals (AllAfrica.com, 2010a). In one cultural exchange, China provided sporting coaches for Mozambican athletes (AllAfrica.com, 2011a). China forgave US\$22 million of debt in 2001 (Horta, 2007) and another US\$20 million in 2007, clearing debt that had accumulated since the 1980s (Ilhéu, 2010). President $\mathrm{Hu}$ Jintao also promised during his 2007 visit to provide US $\$ 170$ million in loans and technical co-operation (Roque, 2009). While these figures seem small, in the Mozambican context they are not insignificant. This gives China a comparatively larger impact-for-investment ratio than in more developed countries (Moss \& Rose, 2006).

\section{$\underline{\text { Investment }}$}

Concessional loans advanced by the Export-Import Bank of China (China Exim) often out-competed similar loans from the World Bank because they were cheaper and free of heavy conditionalities (African Forum and Network on Debt and Development [AFRODAD], 2008). Further, the Chinese completed projects more efficiently than competitors: "They bring everything, they set up everything in place...everything is handled by them... It's very easy and fast" (Nordling, 2011, pp. 560-562). Many loans funded the building of infrastructure, including "roads, bridges, military installations and hospitals" (Horta, 2011, p. 10). Mozambique's transport infrastructure had long needed upgrading, with decades of deterioration adding considerable time and cost to long-distance economic activity. Chinese companies were involved in one third of all road construction during these years, including constructing "important transportation link[s] between the north and south of the country" and with neighbouring countries (Roque, 2009). Chinese funding for major railway projects was also forthcoming.

In the capital Maputo alone, Chinese funding paid for the construction of Mozambique's new National Parliament, Ministry of Foreign Affairs, High Court and National Conference Centre (Ilhéu, 2010). Chinese companies refurbished the symbolically important Polana Hotel, the most luxurious in Maputo (Macauhub, 2009). China funded and built the FIFAapproved 42,000-seat Zimpeto national soccer stadium (Globoport, 2011), and invested more than US\$65 million in the modernisation of Maputo International Airport (Sudan Tribune, 2011). They also began work on a 
Chinese-funded US\$439-million housing project outside Maputo to build a 5,000-house middle-class suburb, accompanied by "roads, schools, clinics and a shopping centre" (The Times - South Africa, 2011). Projects such as building a bridge across Maputo Bay, a road to Mozambique's southern tip, and schemes to decongest city traffic were also being considered (AIM News, 2011). Seventy-two new Chinese-donated diesel buses were also a conspicuous presence in Maputo (Macauhub, 2011a).

More widely, China expanded the Vilanculos aerodrome - a key tourist gateway-(Macauhub, 2010d) and Chinese companies were involved in building urban water supplies (Macauhub, 2010c), cement factories (Cemnet.com, 2010), cotton processing plants (AllAfrica.com, 2010c), and vehicle assembly workshops (AllAfrica.com, 2010b). A still-awaited 'megaproject', the Chinese-funded US\$2.3 billion Mphanda Nkuwu Dam in central Mozambique, was also being discussed with excitement (Horta, 2007).

For agriculture, China built a US\$6 million research centre in Mozambique to facilitate scientific research, training, and technological development ( Macauhub, 2011b), the goal being to eventually increase Mozambican rice production from 100,000 to 500,000 tonnes per year (SciDevNet, 2009). China also proposed plans for developing food production in Mozambique's most fertile province, Zambezia, with a project that would involve huge plantations, cattle fields, canals and up to 3000 Chinese workers (Ilhéu, 2010).

Trade

Meanwhile, bilateral trade between Mozambique and China increased dramatically from US\$120 million in 2006 to US\$690 million by 2010 (Horta, 2011). Mozambique's main exports to China were minerals, and natural resources like wood, oil seeds, cotton, vegetables, and seafood (Ilhéu, 2010); indeed, Mozambique has exported these to China in recent years at higher levels than would be predicted by some empirical trade models, and more than proximate coastal economies such as Kenya and Tanzania (see, for example Johnston, Morgan, \& Wang, 2015). The expansion of mining operations was Mozambique's most dramatic area of development, with investments made by the Brazilian company Vale Moçambique (aiming to sell iron concentrate to China) (Macauhub, 2010a), along with Chinese companies like Wuhan Iron and Steel Corp (Reuters, 2010). Chinese businesses were signalling plans to invest more than US\$13 billion in Mozambique over the subsequent decade in infrastructure, mining, agriculture and tourism, including US\$5 billion in coal mining 
promised by the Chinese company Kingho (Horta, 2011). The modernisation of Beira harbour was projected to facilitate a potential export gateway for Chinese companies in Malawi, Zambia and Zimbabwe (Horta, 2011). In line with Chinese tourism plans, investors began building new five-star hotels around Maputo, worth more than US\$230 million (Hanlon, 2010a). Mozambique's imports from China were, meanwhile, "dominated by vehicles and parts, electrical appliances and iron and steel articles, construction materials and related machinery, manufactured goods, like footwear, bags, electronic products, [and] textiles" (Ilhéu, 2010, p. 54).

\section{Political and Strategic Relations}

Following Mozambique's post-Cold War peace process and inaugural multi-party elections, Sino-Mozambican political relations were oriented towards building stronger political linkages, and facilitating and encouraging growing economic ties. Paula Roque (2009) noted that:

Sino-Mozambican co-operation has for the last ten years centred around high-level diplomatic visits and exchanges of legislative bodies, political parties and government agencies; foreign policy co-ordination in regional and international affairs; and the development of economic and trade cooperation in infrastructure, agriculture and natural resource extraction. (p. 4)

Under the close scrutiny of the media and civil society, Chinese investors went out of their way to win public support in Mozambique while the government did much to ensure the proper regulation of Chinese companies (Roque, 2009). However, the huge potential impact of Chinese investment in Mozambique's economy quickly won over devoted proChinese proselytes in the political class, who were willing to minimise the negatives of engagement with the emerging giant.

\section{Domestic}

Since 2007, a number of high profile Chinese politicians have visited Mozambique, including President Hu Jintao, Foreign Minister Yang Jiechi, as well as a steady stream of lower officials. The Mozambican President Armando Guebuza and Prime Minister (Luísa Diogo and subsequently Aires Ali) travelled to China annually for high-level meetings with their Chinese counterparts (Marks, 2010; Seabra, 2011; Macauhub, 2011c). Mozambique produces minerals such as gold, tantalum and bauxite, and its 
Mozal aluminium smelter is Africa's second largest producer of aluminium. Deposits of other minerals such as copper, iron ore, manganese and titanium have also been discovered (Yager, 2004). Mozambique has three relatively large coal deposits, with reserves estimated at about 2.4 billion tonnes and mines likely to last 35 years. Detected natural gas accumulation were estimated at the time to hold 3.5 trillion cubic feet of gas (Cuvilas, Jirjis, \& Lucas, 2001), and oil had been discovered in Mozambique's north, though not necessarily in commercial quantities (Hanlon, 2010a). Overall, Chinese economic interest, while focused on investment in Mozambique's extractive industries (mining, forestry and agriculture) along with tourism, has been pursued with the perspective of maintaining the long-term, stable relationship needed to develop these resources (Horta, 2011).

\section{Regional}

Mozambique's transport infrastructure is also logistically important to other Chinese projects throughout the region-specifically in neighbouring Zambia, Malawi and Zimbabwe, all of which are landlocked with Mozambique their closest exit to the sea (Horta, 2011). The ports at Maputo, Beira and Nacala all have great potential to service the region, and during the period under study several projects were seeking to base their regional offices in Maputo. China's assistance to upgrade infrastructure relating to harbours, roads and railways would thus benefit Chinese enterprise across the region (Roque, 2009).

\section{Global}

Diplomatically, Mozambique does not have great influence on the world stage, but it does belong to larger associations of interest to China. China has sought to build alliances of states within global institutions capable of defending Chinese interests. To this end, China has exerted effort to broaden its relations with the Portuguese-speaking countries-with annual Lusophone conferences held in Macau (Macauhub, 2010b; Ilhéu, 2010), as well as to forge alliances within the United Nations with the aim of influencing votes regarding China (Pant, 2008).

Within Africa, Mozambique also belongs to the African Union and the Southern African Development Community, which China has also sought to influence politically, and whose interdependent transport systems and increasing economic integration create regional marketing opportunities for investors. Strategically, Mozambique's significance lies in its position on the Mozambique Channel, through which 30 percent of world oil passes (including en route to China) (Seabra, 2011). 
Given that China's potential Great Power-rival India was developing relations with East African states, and upgrading its navy with "state-of-theart aircraft carriers, nuclear submarines, and other surface combatants" (Holslag, 2009, p. 26), China had strategic reasons to establish relations with states throughout the region. The growing threat of piracy in the Indian Ocean, although centred far to the north of Mozambique, also presented a reason for increasing security cooperation regarding shipping along the Mozambican coast (Seabra, 2011). Militarily, however, the SinoMozambican relationship remained very low-level, involving only meetings between defence ministers (Xinhuanet, 2009); technical, logistical and infrastructure assistance in the form of vehicles, computers, uniforms and houses (Chichava, 2008, p. 8); and funding for non-lethal equipment that had risen to US\$3 million a year by 2011(AllAfrica.com, 2008; AIM News, 2010). This stands in contrast with Mozambique's relations with the US military, which was involved in actively training Mozambican forces for peacekeeping and humanitarian operations (Portuguese Institute of International Relations and Security [IPRIS], 2010).

Overall, during this period commentators emphasised that Chinese activity was being watched closely by the media and civil society, and that the Mozambican government remained quite active in ensuring proper regulation of Chinese enterprises (Roque, 2009). However, with the relatively large amount of Chinese aid and investment in Mozambique, it is no surprise that high-level Mozambican politicians continued to praise the relationship or deflect criticism. President Guebuza, for example, characterised those who criticised China as "delirious" (AllAfrica.com, 2011b). A former Mozambican foreign minister noted that, "[i]n the end it's up to us, the Chinese like anyone else have their interests and will plunder us to the extent that we let them" (Horta, 2009).

\section{Sudan and China}

Following decades of British rule over Sudan, independence was granted in 1956 to a national administration dominated by Northern Sudanese officials (Johnson, 1988). Ethnic and religious tensions between Sudan's northern and southern territories would result in two civil wars, one fought primarily between Southern Sudanese militia and the Sudanese military from 1962 to 1972 , and another from 1983 to 2002 between the Southern SPLM/A and central government forces with allied Arab militia (Chapman, 2008; Flint \& de Waal, 2008). During these periods Sudan was ruled by a series of military regimes and unstable democratic governments which were unable to decisively end the conflict with the south (Chapman, 
2008). Sudan has thus had a very turbulent and militarised post-civil war history.

As with other African states, China evoked its shared connections in fighting colonialism in order to construct a portrayal of deep historical connections between the two nations (International Crisis Group, 2012). Low-level political and economic links were forged in Sudan's postindependence period, with sales of fighter jets to Sudan in the late 1960s and the provision of small loan and aid packages in the 1970s. China supported Khartoum in its conflict with southern Sudan, and benefitted politically in 1971 from a failed coup attempt by the Sudanese Communist Party for which Khartoum blamed the Soviet Union (Shinn, 2009). From the 1980s China became a significant source of antipersonnel and antitank mines for Sudan (Human Rights Watch, 2003).

Colonel Omar al-Bashir seized power in Sudan on 30 June 1989, installing a military dictatorship that aimed to maintain power through a national divide-and-rule strategy, using Arab militias to repress insurgencies in troubled regions such as Darfur (Collins, 2008). Most observers were highly critical of the Bashir regime's persecution of minority groups, violations of human rights, and campaigns of 'Arabisation' and 'Islamisation' against non-Arab southerners and Nuba peoples (Adar, 1994; Verney, 1995; Burr \& Collins 2003). As Sudan's relations with the West began to deteriorate, Beijing became the default patron of the regime and was able to gradually expand its influence. International isolation deepened for Sudan from 1993, after it was placed on the United States' list of 'state sponsors of terrorism'. The oil company Chevron had originally invested in Sudan, but by the 1990s had abandoned its concessions. Sudan then invited China to replace Chevron in the Sudanese petroleum industry. This led quickly to a dramatic rise in Chinese activity in Sudan (Shinn, 2009) — driven by China's increasing reliance on imported oil-which included China's increased provision of ammunition, helicopters, military aircraft and armoured vehicles (Human Rights Watch, 2003).

Economically, modern Sudan has been characterised as a failing state, lacking the capacity to effectively govern its remote provinces and provide basic utilities for much of its population (Sudan Tribune, 2012; The Fund for Peace, 2017). Although in the early 1970s Sudan was considered the 'bread basket of the Arab world', the adoption of counterproductive economic policies in line with World Bank and later IMF conditions resulted in "more scarcity, skyrocketing inflation rates, huge budget and balance of payment deficits, economic stagnation and widespread poverty" 
(Maharn, cited in Elhadary \& Samat, 2012, p. 214). International sanctions only intensified these issues. The relationship between China and Sudan was thus, though deeply unequal, a rare source of revenue. However, there is a strong argument that, throughout the period under study, the strong linkage between Chinese investment in Sudan's oil industry and Chinese arms sales to Khartoum meant that the relationship was far from beneficial for the Sudanese population (Human Rights Watch, 2003).

\section{Economic Relations}

\section{Aid}

Prior to 1989 aid was central to China's economic relations with Sudan, though this was composed of only small-scale "barter trade, concessionary loans, arms transfers and medical assistance as well as assorted infrastructure construction projects" and was without significant impact (Large, 2008, pp. 94-95). During these decades, Chinese aid to Sudan remained less than that offered by the World Bank and IMF (Nour, 2011). By 1999 China was providing 17 percent of all loans and grants made to Sudan but, after dwindling in the first years of the millennium, this rose rapidly to 76 percent of loans and grants from 2005-2007. This fell again following the 2008 economic crisis. These figures most likely reflect the divergent aid practices of the West and China in reaction to Sudanese government-sponsored attacks in the Darfur region (Nour, 2011). It has been noted that a majority of this funding went to infrastructure projects, which have wide social benefits while also assisting Chinese extractive industries (Nour, 2011; Yagoob, Adam, \& Zuo, 2015). The Chinese also devote aid to "grandiose and prestigious projects and buildings ... that are perceived as unproductive investment that few traditional donors would be willing to finance" (Nour, 2011, p. 6).

Large (2008) notes that Chinese aid specifically to Darfur emphasised more humanitarian development, including the construction of 120 schools. However, in general China's education-related aid to Sudan was minor and focused on higher degrees in Engineering and the Sciences, implying motivations beyond altruism (Nour, 2011). Nour (2011) concludes that, while implied conditionalities attached to Chinese aid to Sudan-to allow Chinese investment and to purchase Chinese goods - are negative, Chinese aid assists with sustainable development by complementing local investments and facilitating local capacity-building through training. Others concur regarding the positive impacts of Chinese aid projects, though point 
critically to the prominence of loans in Chinese aid (as opposed to grants) as increasing Sudan's external debt burden (Yagoob, Adam, \& Zuo, 2015).

\section{$\underline{\text { Trade }}$}

Sino-Sudanese trade also grew remarkably through this period, as the booming oil-based economy resulted in increasing Sudanese demand for Chinese manufactured goods (Large, 2008). China's role as Sudan's leading trading partner became indisputable, with bilateral trade estimated at around US\$2.56 billion in 2004, US\$3.9 billion in 2005 and US\$5.7 billion in 2007 (Large, 2007, p. 58; Large, 2009, p. 616), and with Sudan importing US\$2.4 billion in manufactured goods from China in 2007 (around 30 percent of all Sudanese imports) (IMF, 2012, p. 467). By 2009, more than half of Sudan's exports were purchased by China, giving it the highest export dependency on China of any African state (Johnston \& Yuan, 2014).

\section{$\underline{\text { Investment }}$}

China's investment in the Sudanese oil industry during the 1990s turned the fledgling industry into the driving force behind Sudan's economic growth, and transformed Sudan into a net oil exporter. Although the American company Chevron invested millions of dollars in oil exploration from the 1970s onwards, civil conflict in Sudan and international pressure eventually forced its withdrawal from the region (Yi-Chong, 2008). The Canadian company Arakis purchased Chevron's concessions in 1992, and in 1996 formed the Greater Nile Petroleum Operating Company in consortium with the China National Petroleum Company (CNPC), Malaysia's Petronas Carigali Overseas Sudan Berhad, and Sudan's national oil company Sudapet Limited, with China owning the largest share (YiChong, 2008; Human Rights Watch, 2003). China's investment in the oil industry increased during the 2000 s with growing profitability and the acquisition of further concessions (Lee, Chan, \& Chan, 2011; Large, 2007). By the late 2000s total Chinese investment in Sudanese oil was estimated at around US $\$ 4.7$ billion, with up to 82 percent of Sudan's oil exports going to Chinese distributors (Shinn, 2009; IMF, 2012, p. 467).

China complemented its investment by employing CNPC's 'construction arm' to build a refinery close to Khartoum, a $1500 \mathrm{~km}$ pipeline to the Red Sea, and engaging in oilfield surface engineering (Human Rights Watch, 2003). As a consequence, the number of Chinese workers living for prolonged periods in Sudan increased threefold between the early 1990s and 2006, reaching a peak of around 24,000 (Hong, 2011), with suggestions 
Chinese convict labour may also have been employed there (Human Rights Watch, 2003; Chellaney, 2010). Chinese economic cooperation in Sudan also secured contracts for large infrastructure projects such as railroads, bridges, communications networks, hydro-electric facilities, the Khartoum airport, textile plants, the (environmentally deleterious) Merowe and Kajbar Dams, and a major water pipeline system (Reeves, 2007; Large, 2008; Foster, Butterfield, Chen, \& Pushak, 2008; Sutter, 2012). However, much of China's infrastructure in Sudan is oriented towards facilitating oil extraction, including the construction of all-weather roads and airstrips, and the Khartoum refinery in which China has a 50 percent stake (Hong, 2011).

Improvement in Sudan's economy throughout this period was largely due to Chinese-led foreign investment in the Sudanese oil industry, with Sudan's GDP increasing by an average of 6 percent annually from 1997 onwards (Abdalla, 2008). Poverty levels in Sudan were said to have declined from 64 to 46 percent between 2005 and 2009 (Abdalla, 2008; Elhadary \& Samat, 2012). Drastically improved economic growth rates and a powerful new political ally enabled Khartoum to cut ties with Western financial institutions in the 1990s and pursue a state-sponsored economic reform program supported by Chinese investment (Elhadary \& Samat, 2012). It has been argued, however, that although "the new and expanding wealth of the Khartoum boom may have been a reality in the capital...very little of this new wealth 'trickled down' into the countryside" (Collins, 2008, p. 238).

\section{Political and Strategic Relations}

While the Chinese Communist Party (CCP) may be an 'old friend' of Sudan, with diplomatic relations dating back to 1959 , China only became important to Sudan's foreign relations from the early 1990s as China's new outreach to Africa coincided with increasing international hostility to Sudan's National Islamic Front (Large, 2008). Growing economic ties were complemented by extensive political contact involving regular tours by leading CCP officials, including former President $\mathrm{Hu}$ Jintao and former Premier Wen Jiabao, and "high-level links between key members of the Sudanese and Chinese governing elite and business executives" (Large, 2007 , p. 58). China used its influence in global institutions, such as the UN Security Council, to block or dilute resolutions detrimental to Sudan (Halper, 2010). In return, al-Bashir's administration favoured Chinese companies when awarding contracts and supported China at international forums by publicly backing China's Tibet and Taiwan policies (Shinn, 2009). However, China's growing concern about being seen as a 
responsible rising power, together with growing criticism of China's conduct by Western and African commentators, made China's non-interference policy increasingly untenable. As a result China's policy towards Sudan underwent slight changes resulting in "the first instance where China actively lobbied an African government to permit a UN mission on its soil...via active brokering and indirect pressure" (Holslag, 2009, p. 30).

Though an economic element, the Sino-Sudanese arms trade was also a central political component of the countries' bilateral relationship. China had a long history of supplying arms to Sudan prior to the 1990s, but this accelerated through the mid-1990s to encompass supply of the vast majority of Sudan's imported small arms, and sophisticated weapons systems such as modern fighter aircraft (Human Rights Watch, 2003; Jakobson, 2009; Shinn, 2009).

From the late 1990s China also helped Khartoum establish what would become the third largest domestic arms industry in Africa, including three weapons factories, one of which was designed for assembling Chinese tanks (Shinn, 2009; Sutter, 2012). Following talks between the Sudanese Armed Forces (SAF) and People's Liberation Army in Beijing in March 2002, military relations rapidly deepened. This manifested in high profile state-to-state diplomatic relations, including talks between senior military figures at the Sudanese Ministry of National Defence in October 2005, and a Chinese tour of the SAF Chief of Joint Staff in April 2007 (Large, 2008). Despite China's emphasis on 'unconditionality' in its relations and noninterference in other nations' internal affairs (Karumbidza, 2007), during this period a 2006 UN panel identified 222 Chinese military vehicles and vast numbers of Chinese shell casings that had been used in the genocidal war in Darfur, spurring claims of Chinese complicity (Shinn, 2009). Various commentators, including the long-time Sudan-watcher Eric Reeves, were damningly critical of China's involvement with Khartoum, arguing that the provision of weapons to the Sudanese government directly supported Bashir's genocidal policies, and that China's support for the regime in the UN Security Council prevented both finding a workable solution to the Darfur conflict and efforts towards regime change (Reeves, 2006; Shinn, 2009; Lee, Chan, \& Chan, 2011).

Ultimately, oil development became "deeply interwoven in patterns of conflict in Southern Sudan” (Large, 2007, p. 59), as enlarged government oil revenues facilitated the development of the Sudanese arms manufacturing industry and the expansion of the Sudanese government war machine aimed at militarily dominating oil-producing areas (Large, 2007). 
On the other hand, later in the period, Chinese pressure on Khartoum was instrumental in persuading al-Bashir's regime to allow a joint UN-African Union peacekeeping mission into the Darfur region (Shinn, 2009).

\section{Conclusions}

Examining the cases of Mozambique and Sudan, in relation to the first criticism that China is primarily motivated in its relations with Africa by extractive economic interests, and that this will only hurt African economies (Large, 2008), in both nations the extraction of primary commodities - oil, gas, and minerals - has certainly been the primary driver of Chinese engagement. However, both case studies demonstrate a more diversified Chinese strategy to win elite and popular support by building infrastructure, improving agriculture, and engaging in broad trade, as well as in training, education and medical care. Rather than simple extraction, this instead seems to point to a mutually beneficial, "balanced and longterm approach to promoting African economic growth" (Hofstedt, 2009, p. 86; Ling, 2010). During the period under study, Chinese trade and investment in Africa did aid development, "if for no other reason than that little investment [was] forthcoming from other sources" (Taylor, 2006, p. 951).

In relation to the second criticism, that China may encourage authoritarianism and corruption, or that China's financial alternatives for African states lessen Western leverage for democratic reform (Alden \& Alves, 2009), this also seems to be the case, albeit with some caveats. China's relations with the government of Sudan demonstrate that its policy of non-interference in states means an acceptance of authoritarianism, while its relationship with the government of Mozambique indicates at least a willingness to turn a blind eye to corruption. However, in both these cases, no significant change in the nature of the regimes followed their deepening of relations with China. China did not create these conditions, though it may help to perpetuate them. Meanwhile, while Chinese support for dubious governments is widely (and rightly) criticised, often little is said about Western relations with authoritarian and corrupt governments, such as those in Gabon, Equatorial Guinea, Angola, Chad or Uganda, to name just a few (Sautman \& Hairong, 2007).

In terms of undermining Western leverage in these states, again this seems to be true. As Arrighi (2007) notes, "China has played a leading role ...in rerouting the Southern [financial] surplus to Southern destinations...thereby relaxing the hold of the IMF and other Northerncontrolled financial institutions on Southern countries" (p. 382); however, 
in the cases of both Mozambique and Sudan, prior Western economic policies were themselves either ineffectual or damaging to the national economies (Jakobson, 2009). Politically, China's undermining of sanctions and the UN arms embargo on Sudan certainly undermined Western efforts to change policies in that country (Shinn, 2009). But it is only in the already isolated state that China became a lifeline for the regime; in the case of Mozambique, its complex political and economic relations regionally and globally mean that the political establishment still has much to lose if threatened with sanctions.

Geo-strategically then, and in relation to the third criticism, was military support an important part of China's relations with African states? And has it posed a human security threat to African civilians? In the case of Mozambique this was a negligible issue, while in Sudan it was of great importance. Chinese military sales and assistance to Sudan were relatively small, but they may have been of great impact. The Darfur genocide would no doubt have taken place regardless, but being willing to passively support these events is shameful. Nevertheless, claims of a Chinese military focus do divert attention from the main military activity taking place in Africa, which is the widespread expansion of American military dominance in the form of the US Africa Command (AFRICOM) under the pretence of fighting terrorism, and through which the US actively participates in combat (Yi-Chong, 2008). Ultimately, beyond minor arms sales, even those who suspect China of nefarious military designs have little evidence to point to (Holslag, 2009).

This analysis of Chinese relations with Mozambique and Sudan has thus confirmed some of the critics' claims, while bringing some conclusions into question. While economic relations were primarily extractive, in the context of an extremely poor economic starting level and with the addition of Chinese aid and development projects, the net economic effects seem to have been positive. Chinese relations may have facilitated corruption and authoritarianism, but they were not the cause; they may have undermined international leverage on states, but seemingly only if that leverage was already minimal; and Western nations themselves have otherwise shamelessly supported many corrupt and authoritarian states in Africa. Finally, while China was willing to provide inappropriate military support in Africa - which may have fed into conflict against civilians - claiming that it was a primary element of China's relations with African states, seems an exaggeration. 


\section{Bibliography}

Abdalla, M. (2008). Poverty and inequality in urban Sudan: Policies institutions and governance. African Studies Collection (Vol. 13). Leiden, NL: African Studies Centre.

Adar, K. (1998). A state under siege: The internationalization of the Sudanese civil war. African Security Review, 7(1), 44-53.

African Forum and Network on Debt and Development (AFRODAD) (2008). Mapping Chinese development assistance in Africa: A synthesis analysis of Angola, Mozambique, Zambia and Zimbabwe. Harare: AFRODAD.

AIM News. (2010). Chinese gift to Mozambique armed forces. 29 December. http://www.mozambiquehighcommission.org.uk/?s=10\&i $\mathrm{d}=384 \&$ new $=$ ok\&grupa $=1$

AIM News (2011). China grants 15.2 million USD for distance learning, science and technology. 11 August. http://www.clubofmozambique. com/solutions $1 /$ sectionnews.php? secao $=$ social development\&id $=22$ 558\& tipo $=$ one

Alden, C. (2007). China in Africa. London: Zed Books.

Alden, C., \& Alves, A.C. (2009). China and African natural resources: The challenges and implications for development and governance. Occasional Paper 41. Johannesburg: South African Institute of International Affairs.

AllAfrica.com. (2008). China supports Mozambican armed forces. 9 December. http://allafrica.com/stories/200812090564.html

AllAfrica.com. (2010a) More Chinese doctors for Mozambique. 20 September. http://allafrica.com/stories/201009220955.html

AllAfrica.com. (2010b) Mozambique: China to fund vehicle assembly plant.

17 December. http://allafrica.com/stories/201012200026.html

AllAfrica.com. (2010c). Mozambique: Chinese banks to invest U.S. \$165 million. 21 June. http://www.focac.org/eng/zxxx/t710674.htm

AllAfrica.com. (2011a). Mozambique and China sign sports agreement. 17 May. http://allafrica.com/stories/201105170907.html

AllAfrica.com. (2011b). President Guebuza lauds cooperation with China.

27 September. http://allafrica.com/stories/201109280211.html

BBC News Online. (2009). China praised for African links. 11 October. http://news.bbc.co.uk/2/hi/8301826.stm

Bräutigam, D. (2010). China, Africa and the international aid architecture. Working Paper107. Tunis: African Development Bank Group.

Bremmer, I. (2010). The end of the free market: Who wins the war between states and corporations? New York: Portfolio. 
Broadman, H.G. (2007). Africa's Silk Road: China and India's new economic frontier. Washington D.C.: The World Bank.

Burr, M., \& Collins, R. (2003). Revolutionary Sudan: Hasan al-Turabi and the Islamist state, 1989-2000. Leiden, NL: Brill.

Campbell, H. (2008). China in Africa: Challenging US global hegemony. Third World Quarterly, 29(1), 89-105.

Carmody, P., \& Taylor, I. (2010). Flexigemony and force in China's resource diplomacy in Africa: Sudan and Zambia compared. Geopolitics, 15, 496-515.

Cemnet.com. (2010). Chinese investors to build cement factory in Mozambique. 18 May. https://www.cemnet.com/News/story/131785/ chinese-investors-to-build-cement-factory-in-mozambique.html

Chellaney, B. (2010). China's newest export: Convicts, The Guardian, 29 July. https://www.theguardian.com/commentisfree/libertycentral/ 2010/jul/29/china-export-convict-labour

Chapman, C. (2008). Why a minority rights approach to conflict? The case of Southern Sudan. London: Minority Rights Group International. http://www.minorityrights.org/6253/briefing-papers/why-a-minorityrights-approach-to-conflict-the-case-of-southern-sudan.html

Chen, W., Dollar, D., \& Tang, H. (2015). Why is China investing in Africa? Evidence from the firm level. https://www.brookings.edu/wpcontent/uploads/2016/06/Why-is-China-investing-in-Africa.pdf

Chichava, S. (2008). Mozambique and China: From politics to business? Lisbon: Instituto de Estudos Sociais e Económicos.

Clinton, H. (2011). America's pacific century. Foreign Policy, 11 October. $\mathrm{http}: / /$ foreignpolicy.com/2011/10/11/americas-pacific-century/

Club of Mozambique. (2016). Amount of China's Aid to Mozambique? "You don't ask a woman her age, you don't ask a trader for numbers". 20 May. http://clubofmozambique.com/news/zhang-mingon-amount-of-chinas-aid-to-mozambique-you-dont-ask-a-womanher-age-and-you-dont-ask-a-trader-for-numbers-either/?platform= hootsuite

Collins, R. (2008). A history of modern Sudan. New York: Cambridge University Press.

Cornelius, P., \& Story, J. (2007). China and global energy markets. Orbis, 51(1), 5-20.

Currier, C., \& Dorraj, M. (Eds.). (2011). China's energy relations with the developing world. New York: Continuum. 
Cuvilas, C. A. R., \& Jirjis, C. L. (2010). Energy situation in Mozambique: A review. Renewable and Sustainable Energy Reviews, 14, 21392146.

Elhadary, Y., \& Samat, N. (2012). Political economy and urban poverty in developing countries: Lessons learned from Sudan and Malaysia. Journal of Geography and Geology, 4(1), 212-223.

Flint, J., \& De Waal, A. (2008). Darfur: A new history of a long war. New York: African Arguments.

Foster, V., Butterfield, W., Chen, C., \& Pushak, N. (2008). Building bridges: China's growing role as infrastructure financier for subSaharan Africa. Trends and Policy Options, 5, 1-146.

Freedom House. (2012). Mozambique. https://freedomhouse.org/report/ freedom-world/2012/mozambique

Friedman, E. (2010). How economic superpower China could transform Africa. In S. Guo \& B. Guo (Eds.), Greater China in an era of globalization (pp. 139-161). Boulder, CO: Lexington Books.

Fund for Peace, The. (2017). Fragile States Index. http://fundforpeace.org/fsi/country-data/

Gaudilliere, P. (2014). From pivot to symmetry? Integrating Africa in the rebalance to Asia. US Foreign Area Officer Association. http://www.faoa.org/Resources/Documents/GAUDILLIERE.pdf

Globoport. (2011). China hands over national stadium to Mozambique. 21 January. http://www.globoport.hu/96130/china-hands-over-nationalstadium-to-mozambique/

Halper, S. (2010). The Beijing consensus: How China's authoritarian model will dominate the twenty-first century. New York: Basic Books.

Hanlon, J. (2010a). Frelimo landslide in tainted election in Mozambique. Review of African Political Economy, 37(123), 92-95.

Hanlon, J. (2010b). Mozambique 174: News reports \& clippings, 13 December, https://www.open.ac.uk/technology/mozambique/sites/ www.open.ac.uk.technology.mozambique/files/pics/d128299.pdf

Hofstedt, T. A. (2009). China in Africa: An AFRICOM response. Naval War College Review, 62(3), 79-100.

Holslag, J. (2009). China's new security strategy for Africa. Parameters, 39(2), 23-37.

Hong, Z. (2011). China's energy relations with Africa. In C. Currier, \& M. Dorraj (Eds.), China's energy relations with the developing world (pp. 101-124). New York, NY: Continuum. 
Horta, L. (2007). China, Mozambique: Old friends, new business, Swiss Federal Institute of Technology. http://www.isn.ethz.ch/isn/CurrentAffairs/Security-Watch/Detail/?id=53470\&lng=en

Horta, L. (2009). China-Africa: Development partner or neo-coloniser? University World News, 29 November. http://www.universityworld news.com/article.php?story $=20091127134020463$

Horta, L. (2011). The Dragon and the Mamba: China's growing presence in Mozambique. China Brief, 11(9), 10-12.

Human Rights Watch. (2003). Sudan, oil, and human rights. http://www.hrw.org/reports/2003/sudan1103/sudanprint.pdf

Ilhéu, F. (2010). The role of China in the Portuguese speaking African countries: The case of Mozambique (Part II), Economia Global $e$ Gestão, 16(1), 41-59.

International Crisis Group. (2012). China's new courtship in South Sudan. Africa Report, 186, 1-38.

International Monetary Fund. (2012). Sudan: Staff report for the 2012 article IV consultation. IMF Country Report, 12(298), 1-77.

IPRIS (Portuguese Institute of International Relations and Security). (2010). IPRIS Lusophone Countries Bulletin, 10.

Jackson, S. F. (1995). China's third world foreign policy: The case of Angola and Mozambique, 1961-93. The China Quarterly, 142, 388422.

Jacques, M. (2009). When China rules the world: The rise of the middle kingdom and the end of the western world. London, UK: Penguin Books Ltd.

Jakobson, L. (2009). China's diplomacy toward Africa: Drivers and constraints. International Relations of the Asia-Pacific, 9, 403-433.

Johnson, D. (1988). The southern Sudan. Minority Rights Group, 78, 1-11.

Johnston, L. A. (2016). China-Africa economic transitions survey: Charting the return of a fleeting old normal. Proceedings of the 38th AFSAAP Conference: 21st Century Tensions and Transformation in Africa, Deakin University. 28-30 October 2015. http://afsaap.org.au/assets/ Lauren Johnston AFSAAP2015.pdf

Johnston, L. A., Morgan, S. L., \& Wang, Y. (2015). The gravity of China's African export promise. The World Economy, 38(6), 913-934.

Johnston, L. A., \& Yuan, C. (2014). China's Africa trade and investment policies: Review of a 'noodle bowl'. The China Monitor, 4, 6-41. http://aeaa.journals.ac.za/pub/article/view/145 
Karumbidza, J. (2007). Win-win economic co-operation: Can China save Zimbabwe's economy? In F. Manji \& S. Marks (Eds.), African perspectives on China in Africa (pp. 87-106). Cape Town: Fahamu.

King, K. (2006). Aid within the wider China-Africa partnership: A view from the Beijing summit. Unpublished Research Paper, London. http://www0.hku.hk/cerc/KK-article/4.China-Africa\%20Partnership. King.2006d.pdf

Large, D. (2007). China and the changing context of development in Sudan. Development, 50(3), 57-62.

Large, D. (2008). China and the contradictions of 'non-interference' in Sudan. Review of African Political Economy, 35(115), 93-106.

Large, D. (2016). China and South Sudan's Civil War, 2013-2015. African Studies Quarterly, 16(3-4), 35-54.

Large, D. (2009). China's Sudan engagement: Changing northern and southern political trajectories in peace and war. The China Quarterly, 199, 610-626.

Lee, P., Chan, G., \& Chan, L. (2011). China in Darfur: Humanitarian rulemaker or rule-taker? Review of International Studies, 38(2), 423-444.

Liang, W. (2008). New Africa policy: China's quest for oil and influence. In S. Guo \& J. Blanchard (Eds.), 'Harmonious world' and China's new foreign policy (pp. 153-172). New York: Lexington Books.

Ling, J. (2010). Aid to Africa: What can the EU and China learn from each other? Occasional Paper 56. Johannesburg: South African Institute of International Affairs.

Macauhub. (2009). Chinese-owned company modernises Mozambique's most luxurious hotel. 9 June. https://macauhub.com.mo/2009/ 06/09/7196/

Macauhub. (2010a). Brazil's Vale to export Mozambican iron ore to China and Oman. 25 May. https://macauhub.com.mo/2010/05/24/9128/

Macauhub. (2010b). China's trade minister says cooperation between China and Portuguese-speaking countries is solution to international crisis. 14 November. https://macauhub.com.mo/2010/11/14/chinas-trademinister-says-cooperation-between-china-and-portuguese-speakingcountries-is-solution-to-international-crisis/

Macauhub. (2010c). Chinese companies take part in modernisation of water supply system in Maputo, Matola and Boane in Mozambique. 13 April. https://macauhub.com.mo/2010/04/13/8898/

Macauhub. (2010d). Chinese company expands and modernises Vilanculos aerodrome, Mozambique. 4 November. https://macauhub.com.mo/ 
2010/11/04/chinese-company-expands-and-modernises-vilanculosaerodrome-mozambique/

Macauhub. (2011a). China gifts buses to Maputo public transport company in Mozambique. 18 July. https://macauhub.com.mo/2011/07/18/chin a-gifts-buses-to-maputo-public-transport-company-in-mozambique/

Macauhub. (2011b). Chinese Ambassador to Mozambique Formally Hands Over Agricultural Research Centre. 12 July. https://macauhub. com.mo/2011/07/11/chinese-ambassador-to-mozambique-formallyhands-over-agricultural-research-centre/

Macauhub. (2011c). Mozambique and China due to sign ten cooperation agreements in Beijing. 11 August. https://macauhub.com.mo/ 2011/08/10/mozambique-and-china-due-to-sign-ten-cooperationagreements-in-beijing/

Macauhub. (2016). Mozambique and China: A fast friendship into the future. 19 August. https://macauhub.com.mo/feature/mozambiqueand-china-a-fast-friendship-into-the-future/

Macauhub. (2017). China participates in the development of Mozambique's natural gas industry. 12 June. https://macauhub.com.mo/feature/ptapoio-chines-viabiliza-nascimento-da-industria-de-gas-naturalmocambicana/

Marks, S. (2010). China's foreign minister completes 6 nation African trip. Pambazuka News, 465, 15 January. http://pambazuka.org/en/ category/emplayersnews/61503

Mohan, G., \& Power, M. (2008). New African choices? The politics of Chinese engagement. Review of African Political Economy, 115, 23 42.

Moss, T., \& Rose, S. (2006). China ExIm Bank and Africa: New lending, new challenges. CGD Notes. Washington, DC: The Center for Global Development.

Naidu, S., Corkin, L., \& Herman, H. (2009). China's (re)-emerging relations with Africa: Forging a new consensus? Politikon, 36(1), 87115.

Nordling, L. (2011). Science in Africa: Enter the dragon. Nature, 474(29), 560-562. www.nature.com/news/2011/110629/full/474560a.html

Nour, S. (2011). Assessment of effectiveness of China aid in financing development in Sudan. UNU-MERIT Working Papers. Maastricht: United Nations University. http://www.eldis.org/document/A63365

Pant, H. (2008). China in Africa: The push continues but all's not well. Defense \& Security Analysis, 24(1), 33-43. 
Poushter, J. (2016). In three African nations, U.S. and China seen as best examples of a developed economy, Fact Tank - Our Lives in Numbers, Pew Research. http://www.pewresearch.org/facttank/2016/11/15/in-three-african-nations-u-s-and-china-seen-as-bestexamples-of-a-developed-economy/

Raine, S. (2009). China's African challenges. New York: The International Institute for Strategic Studies.

Reeves, E. (2006). China in Sudan: Underwriting genocide. www.sudan reeves.org/2006/08/10/china-in-sudan-underwriting-genocide.

Reisinger, C. (2009). A framework for the analysis of post-conflict situations: Liberia and Mozambique reconsidered. International Peacekeeping, 16(4), 483-498.

Reuters. (2010). Riversdale inks $\$ 800 \mathrm{mln}$ coal deal with China. 24 June. http://af.reuters.com/article/commoditiesNews/idAFSGE65M0LB20 $\underline{100624}$

Roque, P.C. (2009). China in Mozambique: A cautious approach. Occasional Paper 23. Johannesburg: South African Institute of International Affairs.

Sautman, B., \& Hairong, Y. (2007). Friends and interests: China's distinctive links with Africa. African Studies Review, 50(3), 75-114.

SciDevNet. (2009). China's farming ambitions in Mozambique take shape. 13 November. http://www.scidev.net/global/biotechnology/news/ china-s-farming-ambitions-in-mozambique-take-shape.html

Scott, D. (2008). The Chinese century?: The challenge to global order. New York, NY: Palgrave Macmillan.

Seabra, P. (2011). Mozambique: Leaning on an external defense umbrella. IPRIS Lusophone Countries Bulletin, 20, 1-2.

Shinn, D. (2009). China and the conflict in Darfur. Brown Journal of World Affairs, 16(1), 85-99.

Smith, J. A. (2011). BRIC becomes BRICS: Changes on the geopolitical chessboard. Foreign Policy Journal, 21 January. www.foreignpolicy journal.com/2011/01/21/bric-becomes-brics-changes-on-the-geopoli tical-chessboard/2/

Stremlau, J. J. (2015). China and Africa's relationship is not yet one of 'win-win economic cooperation', Quartz, 10 December. https://qz.com/570542/china-and-africas-relationship-is-not-yet-oneof-win-win-economic-cooperation/

Sudan Tribune. (2011). China pledges to boost military cooperation with Sudan. 16 November. http://www.sudantribune.com/spip.php ?iframe\&page $=$ imprimable\&id_article $=40748$ 
Sudan Tribune. (2012). Sudan among world's top failed states:Report.20 Jun. www.sudantribune.com/Sudan-among-world-s-top-failed,42975

Sutter, R. (2012). Chinese foreign relations: Power and policy since the Cold War (3rd ed). Plymouth, UK: Rowman \& Littlefield Publishers, Inc.

Taylor, I. (2006). China and Africa: Engagement and compromise. London: Routledge.

Taylor, I. (2008). Sino-African relations and the problem of human rights. African Affairs, 107(426), 63-87.

Times, The (South Africa). (2011). Chinese building \$439m Moz complex. 20 September. http://www.timeslive.co.za/africa/2011/09/20/ chinese-building-439m-moz-complex

Verney, P. (1995). Sudan: Conflict and minorities. London: Minority Rights Group International.

Xinhua. (2008). China 95\% self-sufficiency in grain last ten years. 4 July, www.chinadaily.com.cn/bizchina/2008-07/04/content 6821000.htm

Xinhuanet. (2009) Senior Chinese legislator meets Mozambican defense minister. 6 May. http://www.clubofmozambique.com/solutions1/ sectionnews.php? secao $=$ international\&id $=14971 \&$ tipo $=$ one

Yager, T. R. (2004). The mineral industry of Mozambique. U.S. Geological Survey Minerals Yearbook, 301-304. Washington, DC: U.S. Geological Survey.

Yagoob, A. H., Adam, H. O., \& Zuo, T. (2015). Evaluation of foreign aid from China on Sudan's economic development process. Developing Country Studies, 5(8), 28-36.

Yi-Chong, X. (2008). China and the United States in Africa: Coming conflict or commercial coexistence? Australian Journal of International Affairs, 62(1), 16-37. 